\title{
HYBRID EXCITATION OF THE AXIAL INDUCTOR MACHINE
}

\author{
S. Orlova, V. Pugachov, N. Levin \\ Institute of Physical Energetics, \\ 21 Aizkraukles Str., Riga, LV-1006, LATVIA
}

The paper considers the possibility to use permanent magnets in the rotor slots of axial inductor machine with the aim to create a hybrid excitation of such a machine - from the magnets and from the excitation winding which is placed between the stator cores. The hybrid excitation allows the weight and size parameters of the machine to be improved. Under consideration is a $32 \mathrm{~kW}$ under-carriage generator 2ГВ.13.У1. generator.

Key words: hybrid excitation, permanent magnets, under-carriage inductor

\section{INTRODUCTION}

The axial inductor machine has a simple design and a high degree of reliability. A distinctive design feature of this machine is that it has no rotating windings - all its windings are placed in the stator and fixed. Being classified as those of brushless synchronous type, inductor machines have widely been used in different fields of industry. Such machines (see Fig. 1) are often employed in the electrical power supply systems of trains, planes and ships, as well as in the wind power plants.

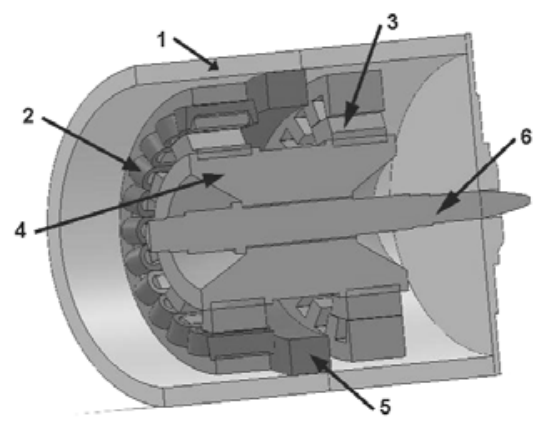

Fig. 1. A two-core axial inductor machine: 1 - body, 2 - armature core with windings, 3 - rotor core, 4 - rotor sleeve, 5 - excitation winding, 6 - shaft.

At the same time, the main disadvantage of axial inductor machines is a low degree of magnetic flux utilisation, because the main magnetic flux at the arbitrary point of air gap changes only from the maximum, $\Phi_{\max }$, under the rotor tooth to the minimum value, $\Phi_{\min }$, in a slot of the rotor (Fig. 2). The flux in the air gap of inductor machine, except the variable component $\left(\Phi_{\max }-\Phi_{\min }\right) / 2$, has a constant component $\left(\Phi_{\max }+\Phi_{\min }\right) / 2$, which additionally loads the stator and rotor magnetic circuits. 


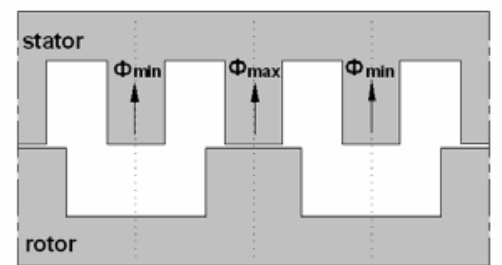

Fig. 2. Magnetic flux distribution in the armature teeth.

The main objective of the axial inductor machine's optimisation is to increase the level of magnetic flux utilisation. This is achieved not only by a rational design of the teeth zone, but mainly by changing the nature of magnetic field in the air-gap of such a machine. For this purpose, in the slots of its rotor the permanent magnets are placed which are oriented in such a way that the flux between the teeth of the rotor changes its direction to the opposite $[2,3]$. Thus, during the process the flux at any point of the air gap changes not only by its magnitude as in conventional inductor machines, but also by direction. Therefore, the first harmonic of the resultant excitation field (i.e. created by a hybrid action of the magnetic force of excitation winding and of the permanent magnets) increases with as the constant component decreases; as a result, a higher level of magnetic flux utilisation is reached. This means that it is possible to significantly improve the weight-size parameters of axial inductor machines.

To estimate the potential of using hybrid excitation in the axial inductor machine, a $32 \mathrm{~kW}$ under-carriage generator of the 2 ГВ.13.У1 type was chosen.

\section{THE USE OF PERMANENT MAGNETS PLACED IN THE ROTOR SLOTS}

Figure 3 shows the curves of fluxes in the tooth area of an axial inductor machine with permanent magnets placed in the rotor slots. In this figure it is seen that the magnetic flux goes mainly through the rotor teeth in the case of electromagnetic excitation, and only its small proportion - through a rotor slot. Placing the permanent magnets into the slots of rotor increases the flux in the slot and changes its direction to the reverse.

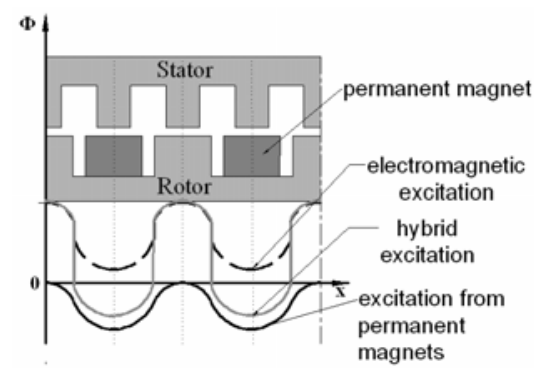

Fig.3. The curves of fluxes in the tooth area.

An axial inductor machine with permanent magnets has the following important advantages in comparison with the conventional:

- a considerable increase in the degree of using the magnetic flux;

- a decrease in the excitation winding magnetomotive force. 
However, apart from the listed advantages, the axial inductor machine with permanent magnets in the slots of rotor has a number of disadvantages as compared with a conventional machine of the type, the main of which are:

- complexity of the rotor design;

- more limited regulation.

\section{TYPES OF THE PERMANENT MAGNETS}

Two main types of permanent magnets can be used in the axial inductor machine: high-power magnets of the $\mathrm{NdFeB}$ type, and low-power magnets based on barium ferrite or strontium ferrite.

Parameters of the magnetic materials are tabulated below.

Table 1

Parameters of permanents magnets

\begin{tabular}{|c|c|c|c|c|c|}
\hline Name & $\begin{array}{c}\text { Type } \\
\text { designation }\end{array}$ & $\mathrm{Br}, \mathrm{T}$ & $\mathrm{Hc}, \mathrm{kA} / \mathrm{m}$ & $\begin{array}{c}(\mathrm{BH}) \mathrm{max}, \\
\mathrm{kJ} / \mathrm{m}^{3}\end{array}$ & $\begin{array}{c}\mu, \\
\text { p.u. }\end{array}$ \\
\hline $\begin{array}{c}\mathrm{BaO}\left(\mathrm{Fe}_{2} \mathrm{O}_{3}\right) \\
\text { or } \\
\mathrm{SrO}\left(\mathrm{Fe}_{2} \mathrm{O}_{3}\right)\end{array}$ & $\Phi \mathrm{M} 33 / 260$ & $0.4 \div 0.42$ & $245 \div 250$ & $32 \div 33$ & 1.3 \\
\hline $\mathrm{NdFeB}$ & $\mathrm{N} 38 \mathrm{EH}$ & $1.22 \div 1.26$ & $>850$ & $>200$ & 1.14 \\
\hline
\end{tabular}

As seen from the table, hard magnetic ferrites are cheap and capable of operating at temperatures up to $250{ }^{\circ} \mathrm{C}$, while the maximum permissible temperature of the $\mathrm{NdFeB}(\mathrm{N} 38 \mathrm{EH})$ magnets is $200^{\circ} \mathrm{C}$.

\section{OBJECT AND RESULTS OF THE RESEARCH}

The research into the possibility to improve the efficiency and size-weight parameters of the inductor machine was carried out based on the under-carriage $2 Г$ В.13.У1 type, $32 \mathrm{~kW}, 700 \mathrm{~kg}$ generator (Fig. 4) used in the railway transport to provide passenger carriages with the air conditioning and heating [4].

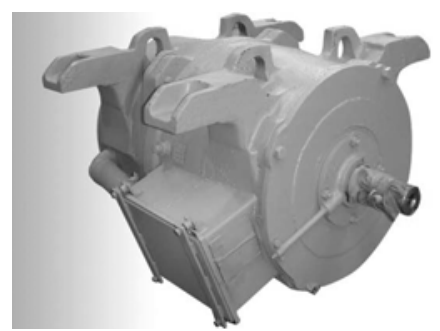

Fig. 4. Under-carriage inductor generator 2ГВ.13.У1.

The main parameters of the generator's tooth zone and its schematic design are presented in Table 2 and Fig. 5, respectively.

The calculation results of the no-load characteristics of axial inductor generator are presented in Fig. 6 for the cases without magnets, magnets with strontium ferrite and $\mathrm{NdFeB}$ magnets. The sizes of magnets correspond to those of rotor teeth. 
The main parameters of the generator's tooth zone

\begin{tabular}{|l|c|c|c|}
\hline \multicolumn{1}{|c|}{ Parameter } & Designation & Value & Unit \\
\hline Number of stator teeth & $Z_{1}$ & 24 & - \\
\hline Number of rotor teeth & $Z_{2}$ & 10 & - \\
\hline Stator tooth pitch & $b_{1}$ & 0.043 & $\mathrm{~m}$ \\
\hline Rotor tooth pitch & $b_{2}$ & 0.1029 & $\mathrm{~m}$ \\
\hline Width of stator tooth & $b_{\mathrm{z} 1}$ & 0.025 & $\mathrm{~m}$ \\
\hline Width of rotor tooth & $b_{\mathrm{z} 2}$ & 0.042 & $\mathrm{~m}$ \\
\hline Width of stator slot & $b_{\mathrm{r} 1}$ & 0.018 & $\mathrm{~m}$ \\
\hline Width of rotor slot & $b_{\mathrm{r} 2}$ & 0.0609 & $\mathrm{~m}$ \\
\hline Length of stator/rotor core & $l$ & 0.115 & $\mathrm{~m}$ \\
\hline Height of stator teeth & $h_{\mathrm{z} 1}$ & 0.036 & $\mathrm{~m}$ \\
\hline Height of rotor teeth & $h_{\mathrm{z} 2}$ & 0.03115 & $\mathrm{~m}$ \\
\hline Stator bore diameter & $D_{\mathrm{S}}$ & 0.3293 & $\mathrm{~m}$ \\
\hline
\end{tabular}

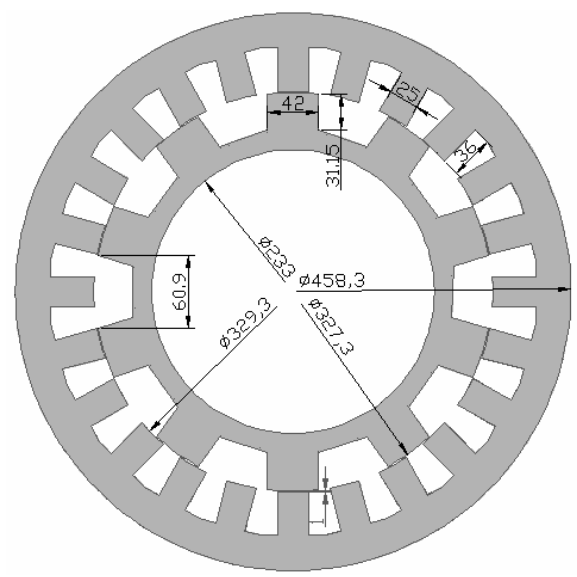

Fig. 5. The tooth zone of generator 2 ГВ.13.2У1 (with the main sizes in $\mathrm{mm}$ ).

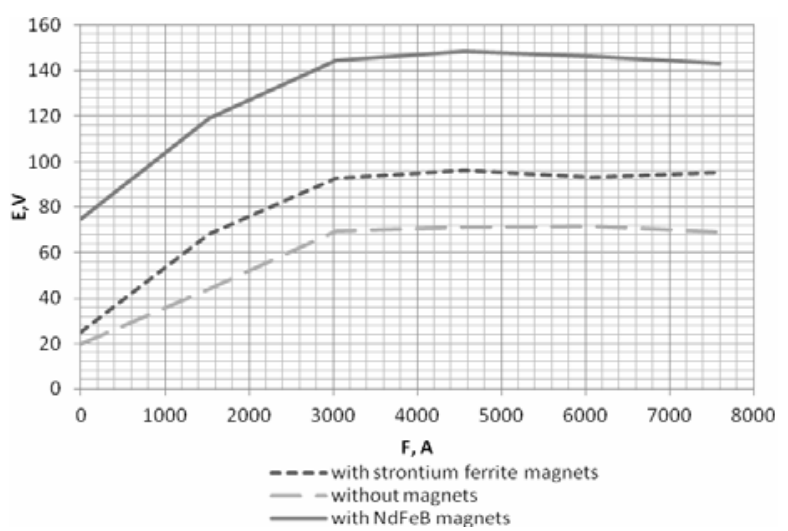

Fig. 6. No-load characteristics of axial inductor generator.

As can be seen from the curves of Fig. 6, the use of strontium ferrite magnets can increase the electromotive force (EMF) by $30 \%$, while that of $\mathrm{NdFeB}$ mag- 
nets - twice. These results mean that a significant improvement of size-weight parameters of the machine can be achieved by increasing the power or reducing the machine sizes. The magnetic field is depicted in Fig. 7 [5].

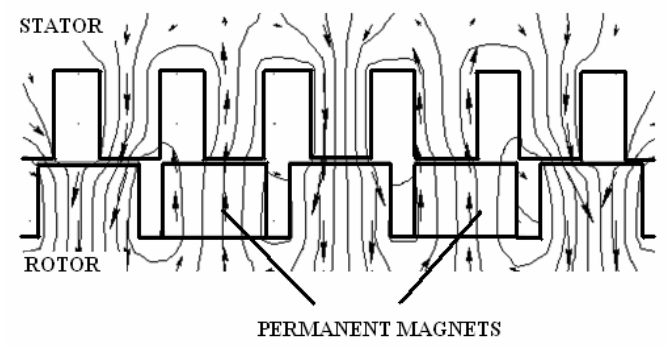

Fig. 7. Magnetic field in the tooth zone.

In this work, reducing the sizes and weight of the machine is achieved by placing NdFeB permanent magnets in the slots of rotor. The magnets had the following sizes:

- $50.8 \mathrm{~mm} \times 25.4 \mathrm{~mm} \times 25.4 \mathrm{~mm}$;

- $76.2 \mathrm{~mm} \times 25.4 \mathrm{~mm} \times 25.4 \mathrm{~mm}$;

- $50.8 \mathrm{~mm} \times 25.4 \mathrm{~mm} \times 12.7 \mathrm{~mm}$;

- $76.2 \mathrm{~mm} \times 25.4 \mathrm{~mm} \times 12.7 \mathrm{~mm}$.

Under investigation was also the magnetic field of generators with $Z_{1}=24$; $Z_{2}=10$ and $Z_{1}=18 ; Z_{2}=10$, using the magnets of different size. Configurations of the machines under consideration are presented in Table 3 . The height of a rotor tooth is equal to that of magnet $(25.5 \mathrm{~mm}$ or $12.7 \mathrm{~mm})$; in turn, the magnet length equals that of the axial core $(50.8 \mathrm{~mm}$ or $76.2 \mathrm{~mm})$.

Table 3

Configurations of the machine

\begin{tabular}{|c|c|c|c|c|}
\hline $\begin{array}{c}\text { Number of } \\
\text { stator teeth }\end{array}$ & \multicolumn{4}{|c|}{ Size of magnet, mm } \\
\hline & Configuration 1 & Configuration 3 & Configuration 5 & Configuration 7 \\
\hline$Z_{1}=24$ & $50.8 \times 25.4 \times 25.4$ & $76.2 \times 25.4 \times 25.4$ & $50.8 \times 25.4 \times 12.7$ & $76.2 \times 25.4 \times 12.7$ \\
\hline & Configuration 2 & Configuration 4 & Configuration 6 & Configuration 8 \\
\hline$Z_{1}=18$ & $50.8 \times 25.4 \times 25.4$ & $76.2 \times 25.4 \times 25.4$ & $50.8 \times 25.4 \times 12.7$ & $76.2 \times 25.4 \times 12.7$ \\
\hline
\end{tabular}

The no-load curves for different generator designs are presented in Fig. 8.

As can be seen from Fig. 8, all configurations with a core length of $76.2 \mathrm{~mm}$ and those with 18 teeth on the stator and 10 teeth on the rotor are described by curves that go higher than those of a conventional generator. The $50.8 \mathrm{~mm} \times$ $25.4 \mathrm{~mm} \times 12.7 \mathrm{~mm}$ magnet has the least volume, which means the least weight $(122.9 \mathrm{~g})$ and lower price. Configuration 6 is therefore optimal.

Which is important, decrease in the core axial length results in a lesser weight of the machine and therefore in a lesser consumption of copper and steel. Comparative tooth zones of the conventional generator with $Z_{1}=24, Z_{2}=10$ and of the optimized one with $Z_{1}=18,2 p=20$ are presented in Fig. 9 . 


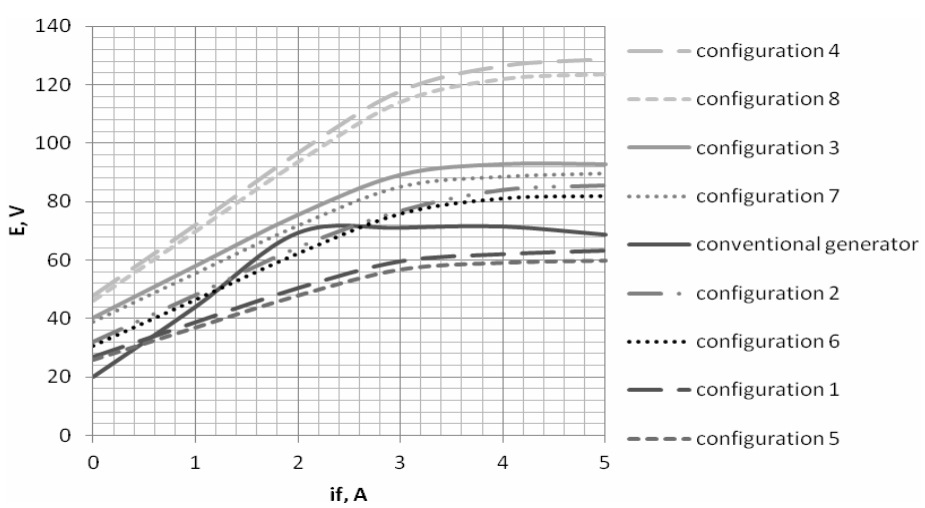

Fig. 8. No-load characteristics of the generators with different tooth zone configurations.

a)

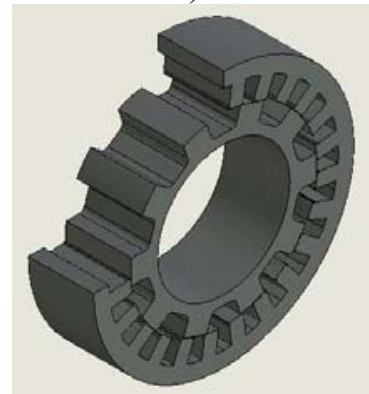

b)

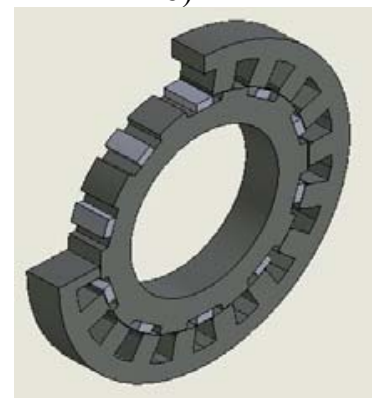

Fig. 9. One core tooth zone of the generators with: a) $Z_{1}=24 ; Z_{2}=10$ and $\left.b\right) Z_{1}=18 ; 2 p=20$.

As can be seen in Fig. 9, the use of permanent magnets makes possible to decrease the core length more than twice (from $115 \mathrm{~mm}$ to $50.8 \mathrm{~mm}$ ), which means that one rotor core becomes $9 \mathrm{~kg}$ lighter, whereas one stator core $-30 \mathrm{~kg}$ lighter. The total decrease in the weight of rotor and stator cores is about $80 \mathrm{~kg}$.

\section{CONCLUSIONS}

The research carried out with the aim to improve efficiency of the axial inductor machine has shown that high-power permanent magnets placed into the rotor slots make possible to reduce significantly the sizes and weight of such a machine maintaining the EMF on the same level. Comparative estimation of the advantages and disadvantages of axial inductor machines with permanent magnets in the slots of rotor allows for conclusion that they have a great potential of using as autonomous power supply sources in diversified applications.

This work was financially supported by European Social Fund, Project "Scientific Group Supporting Latvian Activities of the European Strategic Energy Technology Plan", No.1DP/1.1.1.2.0./09/APIA/VIAA/027.

\section{REFERENCES}

1. Dombur, L.E. (1984). Axial inductor machine. Riga: Zinatne (in Russian).

2. Dombur, L.E., Pugachov, V.A., \& Sika, Z.K. (1966). Two-core inductor machine. Patent USSR 184963 (in Russian). 
3. Dombur, L.E., \& Pugachov, V.A. (1968). Axial inductor machine with permanent magnets. Latv. J. Phys. Tec. Sci., (3), 89-94 (in Russian).

4. Orlova, S. (2011). Optimisation of the inductor generator as an autonomous source of power supply. Summary of Doctoral Thesis. Riga,

5. QuickField User' Guide, version 5.8. WEB http://www.quickfield.com.

\section{AKSIĀLĀ INDUKTORMAŠĪNA AR KOMBINĒTO IEROSMI}

S. Orlova, V. Pugačevs, N. Levins

Kopsavilkums

Šajā darbā apskatītas iespējas pielietot pastāvīgos magnētus aksiālās induktormašīnas rotora rievās. Mašīnai tiek izveidota kombinētā ierosme no pastāvīgajiem magnētiem rotora rievās un no ierosmes tinuma, kas atrodas telpā starp statora paketēm. Kombinētā ierosme ḷauj uzlabot mašīnas masas un gabarītu radītājus. Pētījuma objekts ir zemvagona ǵenerators $2 \Gamma \mathrm{B} .13 . \mathrm{Y} 1$ ar jaudu $32 \mathrm{~kW}$.

20.01.2012. 